\title{
Evaluation of Ground Water Quality with Water Quality Index (WQI) in Woreillu Town, Ethiopia
}

\author{
Melese Damtew Asfaw \\ Mekdela Amba UNiversity, College of Natural and Computational Sciences \\ Department of Chemistry
}

\begin{abstract}
The present work is aimed at assessing the water quality index (WQI) for the groundwater of Wreillu town. The groundwater samples were collected from selected locations within one-year-monitoring period from January to August 2019. All the laboratory measurements of the physical, chemical and heavy metal parameters were measured using the standardized method. The WQI of the study ground water was established from ten physicochemical parameters (temperature, $\mathrm{pH}$, Conductivity, Turbidity, Total alkalinity, TDS, TH, Nitrate, Phosphate, and Sulphate) and five heavy metals ( $\mathrm{Fe}, \mathrm{Cu}, \mathrm{Pb}, \mathrm{Mn}$ and $\mathrm{Zn}$ ). The result showed that all physical and chemical parameters were almost below the maximum allowable level based on the WHO standards for drinking. On the other hand, the lead $(\mathrm{Pb})$ was exceeded the maximum allowable limit in all the studied locations based on the WHO standards for drinking water. The computed WQI values range from 49 to 136 . Therefore, out of 5 studied locations, one location was classified in the "Excellent water" class, one location as a "Good water" class, three as a "Poor water" class. Furthermore, lead, $\mathrm{pH}$ and turbidty were considered the most effective parameter on the determination of WQI in this study. The study revealed that only a few of the values for the heavy metals and physico-chemical parameters of the water samples were above the tolerable limits recommended by the WHO. This calls for regular monitoring and purification of boreholes to ensure good water quality.
\end{abstract}

Keywords: water quality index, drinking water, physico-chemical parameters, heavy metal

DOI: $10.7176 / \mathrm{JEES} / 11-1-02$

Publication date: January $31^{\text {st }} 2021$

\section{Introduction}

Groundwater is a major and important source of water for domestic use in both urban and rural settings and is believed to be among the purest forms of water available in nature (Kumar et al., 2015). Quality drinking water is essential for life but the occurrence of physico-chemical parameters and heavy metals above the permissible standards make it unsafe for drinking (Onwughara et al., 2013). Drinking water affects the health of human beings due to the presence of various dissolved chemical constituents in it (Kumar et al., 2015).

The groundwater is believed to be comparatively much clean and free from pollution than surface water. It can become contaminated naturally or because of numerous types of human activities; residential, municipal, commercial, industrial, and agricultural activities can all affect groundwater quality (Balakrishnan, 2011). The quality of water plays a prominent role in promoting both the standard of agricultural production and human health. Groundwater pollution depends on the inherent hydro geologic property of the site, agricultural land use and cultivation practices (Remesan and Panda, 2008). Contamination of groundwater can result in poor drinking water quality, loss of water supply, high cleanup costs, high costs for alternative water supplies, and/or potential health problems.

Therefore, it is necessary to continue studies to follow the quality of water and investigate pollution problems to take the necessary solutions to reduce the aggravation of environmental problems resulting from it. The WQI concept of water quality for different uses was suggested by Horten in 1965 (Ramadhan et al, 2018). This reflects the interrelated effects of the studied standards in determining water quality and is one of the most effective methods of monitoring surface water pollution (Devojee et al, 2018). As it gives one value instead of the large amount of data that confuses the reader, and thus be understood by the specialist and non-specialist (Al-Hamdany and Al-Saffawi, 2018).

To the best of my knowledge, the evaluation of groundwater quality in Ethiopia by using water quality indices methodologies has not yet been carried out. Thus, the major objective of present study was to evaluate the suitability of groundwater in major groundwater in Woreillu town for drinking purposes based on water quality index approach. Special emphasis was placed on the assessment of the physicochemical and heavy metal properties of the groundwater in major groundwater basins. A secondary objective was to identify the main parameters which may affect the groundwater quality in the each of the studied basins (i.e. the effect of each water quality parameter on the WQI values). The results of this research will allow water managers and policy makers to interpret the groundwater quality conditions for proper actions on groundwater quality management.

Description of the study area

Woreilu is one of the 24 administrative districts in South Wollo Zone of Amhara Region, Ethiopia. It is located at 
$36^{\circ} 26^{\prime} 0^{\prime \prime}-39^{\circ} 43^{\prime} 0^{\prime \prime}$ E longitude and 10 34' $0^{\prime \prime}-10^{\circ} 60^{\prime} 0$ " N latitude and 492km far from Addis Ababa, Ethiopia, $571 \mathrm{~km}$ from Bahir Dar, capital city of Amhara Region, as well as $91 \mathrm{~km}$ from Dessie, West of Zonal

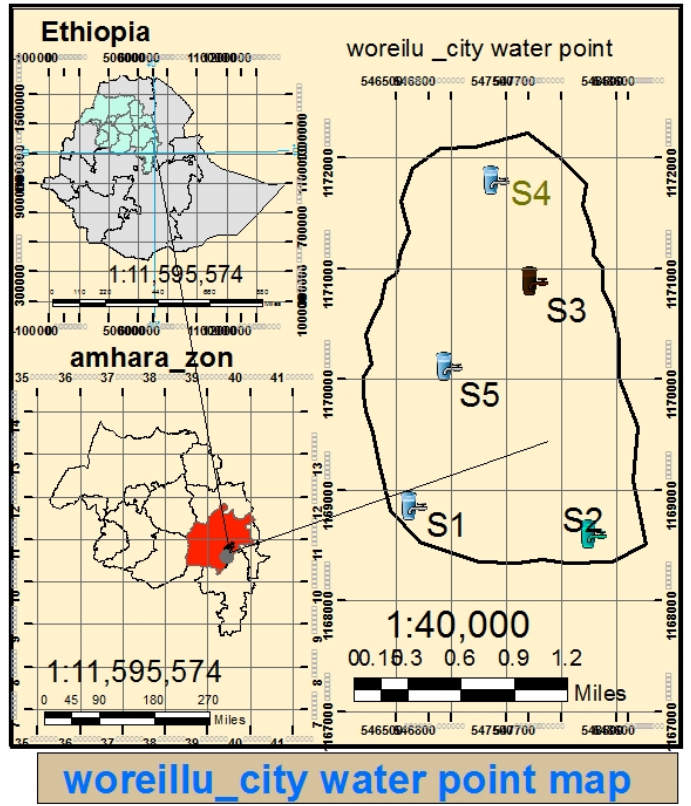

Town. As of 2007 Ethiopia census, Woreilu town had a Population of 14,817 and 71013-hectare total area. According to the Agricultural and Rural Development office of the Woreda, agro-ecologically, the woreda is classified as "Dega" which accounts $82 \%$ while the remaining $18 \%$ is "Woina Dega". From the total number of 23 kebeles administrations 20 are rural. In the Woreda, most Kebeles produce crops in "Meher" season, six kebeles in both seasons and only one kebele in "Belg" seasons. The agro-climatic conditions of the Woreda ranged from moderate to high, with an average altitude of $2730 \mathrm{~m}$ above sea level. Annual rainfall ranges from 766.2 to $1250 \mathrm{~mm}$. which is usually inadequate (short in duration), poorly distributed and highly variable in inter and intra seasons.

\section{Water point sources}

Woreillu town drinking water supply comes from ten water point sources but only five water point sources were purposely selected for this study. The two borehole water sources are located in the northwest; one borehole water sources are located in the southwest, one in the East and one in the West directions of the town. These water point sources are indicated in Table 1.

The co-ordinates points of all the boreholes water sampled were taken using a global positioning system (GPS) (model N20230 etrex Garmin).

Table 1: Sampling locations and their respective point co-ordinates

\begin{tabular}{|l|l|l|l|}
\hline Sample number & Point Coordinates & Sample locations & Designation \\
\hline 1 & $10^{\circ} 34^{\prime} 21.6^{\prime \prime} \mathrm{N} \& 39^{\circ} 25^{\prime} 35.2^{\prime \prime} \mathrm{E}$ & Mume & $\mathrm{S} 1$ \\
\hline 2 & $10^{\circ} 34^{\prime} 13.4^{\prime \prime} \mathrm{N} \& 39^{\circ} 26^{\prime} 28.4^{\prime \prime} \mathrm{E}$ & Abazinab & $\mathrm{S} 2$ \\
\hline 3 & $10^{\circ} 35^{\prime} 27.9^{\prime \prime} \mathrm{N} \& 39^{\circ} 26^{\prime} 10.9^{\prime \prime} \mathrm{E}$ & Konteb & $\mathrm{S} 3$ \\
\hline 4 & $10^{\circ} 36^{\prime} 56.9^{\prime \prime} \mathrm{N} \& 39^{\circ} 25^{\prime} 47.2^{\prime \prime} \mathrm{E}$ & Jegola & $\mathrm{S} 4$ \\
\hline 5 & $10^{\circ} 35^{\prime} 2.7^{\prime \prime} \mathrm{N} \& 39^{\circ} 25^{\prime} 45.9^{\prime \prime} \mathrm{E}$ & Agamti & $\mathrm{S} 5$ \\
\hline
\end{tabular}

Fig. 1. Location map of the study area with the location of groundwater sampling site

\section{Methodology}

\section{Calculation of the WQI}

In this study, the WQI for groundwater was calculated by the weighted arithmetic mean method (Brown et al., 1970) with respect to the WHO standards for drinking water (WHO, 2011). The methodology of calculating WQI can be summarized in the following five steps:

\section{Parameter selection}

According to the World Health Organization (WHO), the priority parameters that should be considered in any drinking water quality assessment are those that have the greatest health impact and are most commonly detected at significant concentrations in drinking water (WHO, 2011). Thus, fifteen parameters were selected in this study to calculate WQI (Temperature, $\mathrm{pH}$, electrical conductivity (EC), total dissolved solid (TDS), total hardness (TH), turbidity (Turb), Alkalinity, sulphates $\left(\mathrm{SO}_{4}{ }^{2-}\right)$, nitrates $\left(\mathrm{NO}_{3}{ }^{-}\right)$, phosphate $\left(\mathrm{PHO}_{4}{ }^{3-}\right)$, copper $(\mathrm{Cu})$, zinc $(\mathrm{Zn})$, lead $(\mathrm{Pb})$, iron $(\mathrm{Fe})$ and manganese $(\mathrm{Mn})$. 
The groundwater samples were collected from selected locations within one-year-monitoring period from January to August 2019. All sampling steps, including samples preservation and the analysis of all parameters were carried out according to the standard methods for water and wastewater (APHA, 2005).

\section{Unit weight assignment for each parameter}

First, a unit weight was assigned to each of the parameters under consideration (wi) according to its health effects when present in drinking water - Table 2. The maximum weight assigned is five (the highest effect on drinking water quality) and the minimum weight assigned is one (the least effect on drinking water quality). Then, the relative weight for each parameter $(\mathrm{Wi})$ is calculated by dividing its unit weight by the sum of unit weight of all parameters as per the following formula:

$$
\mathrm{Wi}=\frac{w i}{\sum_{i=1} w t}
$$

Where: $W i$ is the relative weight,

$w i$ is the unit weight of each parameter and $\mathrm{n}$ is the number of selected parameters $(n=15$ in this study) and calculated relative weight (Wi) value of each parameter are also given in Table 2.

Table 2. The unit weight and relative weight of each parameters used for WQI computation with WHO standard for drinking water quality

\begin{tabular}{|l|l|l|l|}
\hline Parameters & Standard & Unit weight & Relative weight \\
\hline Temperature $\left({ }^{\circ} \mathrm{C}\right)$ & 25 & 1 & 0.0213 \\
\hline $\mathrm{P}^{\mathrm{H}}$ & $6.5-8.5$ & 4 & 0.0851 \\
\hline $\mathrm{EC}(\mu \mathrm{S} / \mathrm{Cm})$ & 1000 & 4 & 0.0851 \\
\hline Turbidity $(\mathrm{NTU})$ & 5 & 3 & 0.0638 \\
\hline TDS $(\mathrm{mg} / \mathrm{L})$ & 1000 & 4 & 0.0851 \\
\hline TH $(\mathrm{mg} / \mathrm{L})$ & 500 & 3 & 0.0638 \\
\hline Alkalinity $(\mathrm{mg} / \mathrm{L})$ & 200 & 2 & 0.0426 \\
\hline Nitrate $(\mathrm{mg} / \mathrm{L})$ & 50 & 5 & 0.1064 \\
\hline Phosphate $(\mathrm{mg} / \mathrm{L})$ & 5 & 1 & 0.0213 \\
\hline Sulphate $(\mathrm{mg} / \mathrm{L})$ & 250 & 4 & 0.0851 \\
\hline $\mathrm{Fe}(\mathrm{mg} / \mathrm{L})$ & 0.5 & 3 & 0.0638 \\
\hline $\mathrm{Cu}(\mathrm{mg} / \mathrm{L})$ & 2 & 2 & 0.0426 \\
\hline $\mathrm{Pb}(\mathrm{mg} / \mathrm{L})$ & 0.01 & 5 & 0.1064 \\
\hline $\mathrm{Mn}(\mathrm{mg} / \mathrm{L})$ & 0.4 & 4 & 0.0851 \\
\hline $\mathrm{Zn}(\mathrm{mg} / \mathrm{L})$ & 4 & 2 & 0.0426 \\
\hline & $\sum$ & $\sum w i=47$ & $\sum W i=0.9983$ \\
\hline
\end{tabular}

\section{Calculation of the rating scale for each parameter}

Rating scale transforms the different units and dimensions of water quality parameters to common scale. The rating scale $(Q i)$ for each parameter is calculated by dividing its concentration by its permissible limit value as defined in WHO and the result multiplied by 100 according to the following equation:

$$
\text { Qi }=\frac{C i}{S i} x 100
$$

Where, $\mathrm{Qi}$ is the quality rating, $\mathrm{Ci}$ is the concentration of each parameter in each water sample, and $\mathrm{Si}$ is the WHO drinking water standard for each parameter.

\section{Developing sub-indices}

The water quality sub-index value $(S I i)$ is determined for each parameter by multiplying its relative weight $(W i)$ with its rating scale $(Q i)$ as follows:

$$
\text { SI } i=\text { WixQi }
$$

Where: $S I i$ is the sub-index value for $i^{\text {th }}$ parameter.

\section{Aggregation of sub-indices}

In this study, additive aggregation is applied to obtain the water quality index (WQI). Thus, the WQI is the sum of sub-indices of all selected parameters as per the following equation:

$$
\mathrm{WQI}=\sum \mathrm{SIi}
$$

The groundwater quality types were determined according to the computed WQI values. These types were classified into five categories (Sahu \& Sikdar, 2008), as shown in Table 3.

Table 3. The WQI range and water quality classification for drinking purposes

\begin{tabular}{|l|l|l|l|l|l|}
\hline WQI values & $<50$ & $50-100$ & $100.1-200$ & $200.1-300$ & $>300$ \\
\hline Degree & & & & & \\
\hline Category & I & II & III & IV & V \\
\hline
\end{tabular}




\section{Effective weight calculation}

In order to accomplish the second objective, the effect of each water quality parameter on the WQI values was calculated by its effective weight. The effective weight $(E W i)$ for each parameter was determined by dividing its sub-index value (SIi) by the WQI value at a given sampling location and the result was multiplied by 100 as in the following equations (Sener et al., 2017):

$$
\mathrm{WQI}=\sum \mathrm{SIi}
$$

Where: $E W i$ is the effective weight value for $i^{\text {th }}$ parameter

\section{Results and discussion}

Understanding the groundwater quality is very important, because it is the main factor which decides its suitability for different purposes (domestic, agricultural and industrial). The chemical composition of groundwater is the result of the geochemical processes occurring due to the reaction of water and geologic materials (aquifer) through which it flows. It is also influenced by other natural and anthropogenic factors that affect the quality of groundwater.

High potable water temperature may impart undesirable taste and odour as well as the corrosive ability of the water (WHO 2011). This may also facilitate the growth of microorganisms, hence affecting water quality (WHO 2011). In this study, sample temperatures were between 11 and $16^{\circ} \mathrm{C}$ (Table 4). These temperatures were all within the WHO maximum limit of $25^{\circ} \mathrm{C}$. The relatively low sampling temperature recorded could be attributed to the time of collection of the samples which was in the morning. Nkansah and Ephraim (2009) reported low temperature in the physicochemical analysis of water in Ghana which they attributed to the time of sampling. The temperature of drinking water is often not a major concern to consumers especially in terms of the quality. The quality of water with respect to temperature is usually left to the individual taste and preference.

The $\mathrm{pH}$ values ranged from 7.8 to 8.3 which indicate the slightly alkaline nature of groundwater in all studied locations and all values were within the WHO permissible limits of drinking water. The alkaline nature of groundwater is mainly caused by bicarbonate concentration in the water aquifers. The $\mathrm{pH}$ of water is important because it controls many of the geochemical reactions or solubility calculations within groundwater. Moreover, $\mathrm{pH}$ is an important operational parameter in treatment plant. The $\mathrm{pH}$ must be controlled within a favorable range for chemical processes in coagulation, disinfection, softening and corrosion control. Failure to minimize corrosion (corrosion occur at low $\mathrm{pH}$ ) can result in the contamination of drinking water and aesthetic problems.

Electrical conductivity gives an account of all the dissolved ions in solution. In this study, the conductivity values ranged from 0.3 to $0.35 \mu \mathrm{S} / \mathrm{cm}$ (Table 4). All the values obtained were below the WHO 2011 maximum permissible limit of $1000 \mu \mathrm{S} / \mathrm{cm}$ for drinking water and therefore, the electrical conductivity values recorded from the samples do not have any potential health risk to the consumers. Electrical conductivity is considered to be a good and rapid measure of determining total dissolve solids as reported by Quaitto, (1996).

Turbidity is an indication of the clarity the water. The turbidity of the water samples showed wide variations ranging from 3.1 to as high as $6.8 \mathrm{NTU}$ (Table 4). The turbidity values of all the samples were within the maximum acceptable limits of the WHO standard except samples from S4 (Jegola) whose turbidity was 6.8 NTU. Generally, borehole water usually has low turbidity value since surface water that percolate as groundwater would have undergone natural filtration through the soil as it percolates into the aquifer. However, the significant values obtained in some of the borehole analyzed signified a possible clay and groundwater interaction in some aquifers which is capable of influencing the clarity of the water. Tiimub et al., (2012), reported turbidity of 0.59-23.3 in underground water analysis and attributed it to clay and underground water interaction.

Total dissolved solids (TDS) in drinking water have been associated with natural source, sewage, industrial wastewater, urban run-off and chemicals used in water treatment process (Environmental Protection Agency, Ghana 2002). High concentrations of TDS may confer undesirable taste, odour and colour on water, posing adverse reactions to the consumer (Spellman and Drinan 2012). The TDS in this study exhibited a wide variation with a minimum value of $193 \mathrm{mg} / \mathrm{l}$ and a maximum value of $234 \mathrm{mg} / 1$ (Table 4). All the TDS values were below the maximum allowable value of $1000 \mathrm{mg} / \mathrm{l}$ prescribed by the WHO (2011). All the sample locations are classified as fresh water type (TDS $<1000 \mathrm{mg} / \mathrm{L}$ ). Moreover, the palatability of drinking water can be classified according to TDS as excellent $(<300 \mathrm{mg} / \mathrm{L})$, good $(300-600 \mathrm{mg} / \mathrm{L})$, fair $(600-900 \mathrm{mg} / \mathrm{L})$, poor $(900-1200 \mathrm{mg} / \mathrm{L})$ and unacceptable (>1200 mg/L) (WHO, 1996). According to this categorization, all of the studied locations can be classified as excellent water.

Total hardness is chemically expressed as the total concentration of $\mathrm{Ca}^{2+}$ and $\mathrm{Mg}^{2+}$ as milligram per liter equivalent of $\mathrm{CaCO}_{3}$ (Nitsch et al. 2000). Physically, hardness could be referred to as the resistance of water to lather soap (Todd 2008). The total hardness values recorded ranged from 148 to $263 \mathrm{mg} / \mathrm{l}$ for all the samples analysed (Table 4). The total hardness measurements for all the samples were below the $500 \mathrm{mg} / \mathrm{l}$ recommended by the WHO for drinking water (Table 4), suggesting that they were all compliant with the WHO guideline and also safe for drinking. Sawyer et al. (2003) classified groundwater according to TH as soft $(\mathrm{TH}<75)$, moderately hard $(75<\mathrm{TH}<150)$, hard $(150<\mathrm{TH}<300)$ and very hard $(\mathrm{TH}>300)$. Adopting these classification criteria, the groundwater of the majority of the studied locations is moderately hard to hard water. Out of the 5 sampling 
locations, only one location belongs to moderately hard water and the rest four locations belong to hard water. Hard water is not a health concern below the permissible level, but may affect the acceptability of drinking water (WHO, 2011a). Hard water can be a nuisance within the home. TH greater than $80 \mathrm{mg} / \mathrm{L}$ cannot be used for domestic purposes, because it coagulates soap lather (Sujatha \& Reddy, 2003). Additionally, hard water can cause scale deposition in the water distribution system, as well as in heated water applications (WHO, 2011b).

Alkalinity is the acid neutralizing ability of the water (United States Environmental Protection Agency 2012). Alkalinity of water is mainly caused by the presence of ions such as $\mathrm{HCO}_{3}{ }^{-}, \mathrm{CO}_{3}{ }^{2-}$ or $\mathrm{OH}^{-}$in ground water (United States Environmental Protection Agency 2012). We identified that alkalinity of the water samples was fairly low and within the WHO standard (Table 4) with a mean alkalinity value of 121 to $179 \mathrm{mg} / \mathrm{l}$. The result of the analysis showed that the value of total alkalinity content of borehole water of Woreillu town in all sampling sites were within WHO limit of $200 \mathrm{mg} / \mathrm{l}$ and fit for drinking purposes.

The nitrates concentration varies from 0.17 to $0.23 \mathrm{mg} / \mathrm{L}$ in the studied locations. All the borehole water analyzed showed appreciable levels of nitrates which were still below the WHO 2011 maximum permissible limit of $50 \mathrm{mg} / 1$ and therefore do not pose adverse health risk to consumers. The adverse effect of nitrate can only occur at elevated level above $50 \mathrm{mg} / \mathrm{l}$, especially in children causing methemoglobinemia blue baby syndrome (WHO, 2004). The availability of nitrate in appreciable quantities in all the boreholes analyzed signified a common possible source of nitrates in the entire sample which is suspected to originate from the farming practices that are common in the study area. All the boreholes analyzed were within the vicinity of farm lands that involved the application of organic manure and inorganic fertilizers. Mancy (2012) reported availability of nitrate in the analyzed water sample and identified agricultural activities which included fertilizer and organic manure application as the possible sources of contamination.

Phosphorous in water occurs mainly in orthophosphate, condensed phosphate and organically bound phosphate. The microbial detraction of organic matter releases the phosphorous in phosphate form. Phosphorus occurs naturally in rocks, soil, animal waste, plant material, and even the atmosphere. In addition to these natural sources, phosphorus comes from human activities such as agriculture, discharge of industrial and municipal waste, and surface water runoff from residential and urban areas. The significance of phosphorous lies in its ability to cause eutrophication water in presence of other nutrients, especially nitrogen (Thriodore, 2004). In the study area, mean phosphate concentration in the samples varied between 0.1 to $0.65 \mathrm{mg} / \mathrm{l}$ (Table 4).

The concentration of phosphate encountered in the natural water environment is normally not enough to causes any detrimental health effect on humans or animals. Phosphate like any other nutrient is harmless in lower concentrations but become harmful only in higher doses. Higher doses of Phosphate are known to interfere with digestion in both humans and animals. The phosphate concentrations of the samples analyzed were all within the acceptable limit and therefore do not pose any health risk to the consumers. The presence of phosphate in all the borehole waters analyzed could be an indication that the source of phosphate in water samples may be of the same origin.

Sulphate is among the major anions commonly found in fresh water resources. The sulphate concentration in the studied locations ranges between 4.4 and $23 \mathrm{mg} / \mathrm{L}$. Sulphate can only adversely affect the health of human consumers in high concentration above $500 \mathrm{mg} / \mathrm{l}$ and causes laxative effect when combine with calcium and magnesium, the two most common components of hard water. The guideline values of 250mg/l USEPA (2012) as above were established for sulphates based on taste consideration not on health reason. Therefore, sulphates do not pose adverse health risk to the consumers of the sampled water since all samples recorded values below $500 \mathrm{mg} / 1$ which is limit that has health implication.

High concentration of iron in groundwater may not pose any health hazards but may not be patronized by consumers due to unpleasant odour and taste that is normally associated with underground water with higher iron concentrations (Gardner and Pelig-Ba 1995). The mean level of iron in the water samples analysed for the entire period ranged from 0.15 to $0.53 \mathrm{mg} / 1$ (Table 4). The highest value of $0.53 \mathrm{mg} / \mathrm{l}$ was recorded at S5 (Agamti) and the lowest value was recorded at S2 (Abazinab) of $0.15 \mathrm{mg} / \mathrm{l}$ (Table 4). The values were above the acceptable limit of prescribed by WHO at Agamti. The analyses have shown that $20 \%$ of the borehole water had iron concentrations above WHO recommended limit for drinking water. High iron concentrations in groundwater are widespread and sometimes underrated constraints in water supply. This may be due to the appreciable quantity of iron detected in all the samples may be as result of common source of contamination which is probably from the iron bearing minerals in the rocks as they interact with the under-borehole water. The pipes used in the construction of the boreholes could also be a possible source of contamination.

Copper concentration in water samples varied from 0.09 to $0.13 \mathrm{mg} / 1$ (Table 4). Copper levels were highest at S4 (Jegola) and the lowest recorded at S1 (Mume). The values were within the acceptable limit of $2.0 \mathrm{mg} / 1$ prescribed by WHO (2011). Copper may be found in water through the natural process of dissolution of minerals, industrial discharge, through its use as copper sulphate for controlling biological growth in some reservoirs and distribution system or through copper corrosion of copper alloy water pipes but most copper contamination in drinking water happens in the water delivery system as a result of corrosion of copper pipes or fittings (ASTM, 
2004).

The mean level of lead in the water samples analysed for the entire period ranged from 0.02 to $0.1 \mathrm{mg} / 1$ (Table 4). The highest value of $0.1 \mathrm{mg} / 1$ was recorded at $\mathrm{S} 1$ (Mume) and the lowest value of $0.02 \mathrm{mg} / \mathrm{l}$ were recorded at S2 (Abazinab) and S3 (Konteb). Lead was found in all the sampling sites and to be higher than $0.01 \mathrm{mg} / \mathrm{l}$, recommended limit of WHO (2011) for drinking water. This makes the water unsuitable for human consumption as $\mathrm{Pb}$ is known to be toxic even at low levels with resultant ill-health effects as chronic exposure has been linked to growth retardation in children (Bowell et al., 1996). The possible causes of high lead concentration in these boreholes water is rather very surprising being a rural environment. Nonetheless, increased use of chemical fertilizer due to rapidly declining soil fertility in the study may have accounted for high lead contamination of the groundwater. Moreover, the recorded high level of lead in the sampled water signified a possible rock mineral and groundwater interaction. The underlying rocks may contain minerals of lead composition capable of impacting lead on the ground water.

The mean level of manganese in the water samples for the entire period ranged from 0.04 to $0.11 \mathrm{mg} / 1$ (Table 4). All the values obtained in all the water samples were below the WHO 2011 maximum permissible limit of $0.4 \mathrm{mg} / \mathrm{l}$. The detectable levels of manganese in all the samples analyzed could mean that the source of contamination is common to all the boreholes and is probably due to the dissolution of minerals of manganese in the underground water. Manganese occurs as a result of weathered and solubilized manganese from soil and bedrock (Ward, 1995).

The mean level of zinc in the water samples analysed for the entire period ranged from 0.27 to $1.1 \mathrm{mg} / 1$ (Table 4). The highest value of $1.1 \mathrm{mg} / \mathrm{l}$ was recorded at S5 (Agamti) and the lowest value of $0.27 \mathrm{mg} / \mathrm{l}$ was at $\mathrm{S} 3$ (Konteb). However, zinc concentrations in all the borehole waters were all within the WHO acceptable limit for drinking water. Zinc is considered an essential trace metal which functions as a catalyst for enzymatic activity in human bodies. Drinking water contains this trace metal in very small quantities which may reduce the possibility of its deficiency in the diet.

In general, the presence of heavy metals in drinking water is a threat to human health considering their strong toxicity even at very low concentration. The toxicity level and the adverse effect depend on the heavy metal species. The adverse effects of heavy metals include reduced growth and development, nervous system damage, development of autoimmunity and liver or kidney damage. Few heavy metals can bioaccumulate in the human body (e.g., in lipids and the gastrointestinal system) and may induce cancer (Chowdhury et al., 2016). At higher doses, heavy metals can cause irreversible brain damage and in extreme cases, death (Barakat, 2011).

Table 4. Measured groundwater quality parameters used in this study at each sampling location, data represents the mean values of the monitoring period. The minimum and maximum values are among the sampling locations.

\begin{tabular}{|c|c|c|c|c|c|c|c|c|}
\hline \multirow[t]{2}{*}{ Parameters } & \multicolumn{5}{|c|}{ Sampling Sites } & \multirow[t]{2}{*}{ Max } & \multirow[t]{2}{*}{ Min } & \multirow[t]{2}{*}{ Mean } \\
\hline & S1 & S2 & S3 & S4 & S5 & & & \\
\hline $\begin{array}{l}\text { Temperature } \\
\left({ }^{\circ} \mathrm{C}\right)\end{array}$ & $13.55 \pm 0.29$ & $12.82 \pm 0.29$ & $11 \pm 0.05$ & $15 \pm 0.35$ & $16 \pm 0.49$ & 16 & 11 & 13.7 \\
\hline $\mathrm{P}^{\mathrm{H}}$ & $7.8 \pm 0.70$ & $8.1 \pm 0.40$ & $7.9 \pm 0.03$ & $7.9 \pm 0.40$ & $8.3 \pm 0.00$ & 8.3 & 7.8 & 8 \\
\hline $\mathrm{EC}(\mu \mathrm{S} / \mathrm{Cm})$ & $0.3 \pm 0.01$ & $0.33 \pm 0.00$ & $0.35 \pm 0.01$ & $0.30 \pm 0.01$ & $0.35 \pm 0.02$ & 0.35 & 0.3 & 0.33 \\
\hline $\begin{array}{l}\text { Turbidity } \\
\text { (NTU) }\end{array}$ & $3.89 \pm 0.03$ & $3.8 \pm 0.01$ & $4.1 \pm 0.11$ & $6.8 \pm 0.17$ & $3.1 \pm 0.05$ & 6.8 & 3.1 & 4.3 \\
\hline TDS (mg/L) & $198.5 \pm 0.71$ & $210 \pm 0.00$ & $234 \pm 0.50$ & $193 \pm 5.20$ & $207 \pm 5.10$ & 234 & 193 & 208.5 \\
\hline $\mathrm{TH}(\mathrm{mg} / \mathrm{L})$ & $178.5 \pm 0.00$ & $263 \pm 1.04$ & $215 \pm 0.05$ & $197 \pm 0.15$ & $148 \pm 3.06$ & 263 & 148 & 200.3 \\
\hline $\begin{array}{l}\text { Alkalinity } \\
(\mathrm{mg} / \mathrm{l})\end{array}$ & $165 \pm 0.21$ & $121 \pm 0.00$ & $169 \pm 0.80$ & $179 \pm 0.20$ & $140 \pm 1.38$ & 179 & 121 & 154.8 \\
\hline $\begin{array}{l}\text { Nitrate } \\
(\mathrm{mg} / \mathrm{L})\end{array}$ & $0.18 \pm 0.00$ & $0.19 \pm 0.02$ & $0.23 \pm 0.07$ & $0.19 \pm 0.00$ & $0.17 \pm 0.01$ & 0.23 & 0.17 & 0.19 \\
\hline $\begin{array}{l}\text { Phosphate } \\
\text { (mg/L) }\end{array}$ & $0.65 \pm 0.05$ & $0.25 \pm 0.00$ & $0.10 \pm 0.00$ & $0.58 \pm 0.03$ & $0.27 \pm 0.01$ & 0.65 & 0.1 & 0.37 \\
\hline $\begin{array}{l}\text { Sulphate } \\
(\mathrm{mg} / \mathrm{L})\end{array}$ & $22 \pm 0.58$ & $14.4 \pm 0.35$ & $23 \pm 0.23$ & $5.5 \pm 0.03$ & $4.4 \pm 0.57$ & 23 & 4.4 & 13.9 \\
\hline $\mathrm{Fe}(\mathrm{mg} / \mathrm{L})$ & $0.21 \pm 0.001$ & $0.15 \pm 0.004$ & $0.17 \pm 00.02$ & $0.28 \pm 0.002$ & $0.53 \pm 00.03$ & 0.53 & 0.15 & 0.27 \\
\hline $\mathrm{Cu}(\mathrm{mg} / \mathrm{L})$ & $0.09 \pm 0.002$ & $0.10 \pm 0.001$ & $0.10 \pm 0.000$ & $0.13 \pm 0.00$ & $0.11 \pm 0.000$ & 0.13 & 0.09 & 0.11 \\
\hline $\mathrm{Pb}(\mathrm{mg} / \mathrm{L})$ & $0.10 \pm 0.002$ & $0.02 \pm 0.001$ & $0.02 \pm 0.00$ & $0.08 \pm 0.001$ & $0.09 \pm 0.003$ & 0.1 & 0.02 & 0.07 \\
\hline $\mathrm{Mn}(\mathrm{mg} / \mathrm{L})$ & $0.11 \pm 0.00$ & $0.05 \pm 0.002$ & $0.04 \pm 0.001$ & $0.04 \pm 0.000$ & $0.07 \pm 0.00$ & 0.11 & 0.04 & 0.06 \\
\hline $\mathrm{Zn}(\mathrm{mg} / \mathrm{L})$ & $0.51 \pm 0.002$ & $0.69 \pm 0.005$ & $0.27 \pm 0.003$ & $0.38 \pm 0.001$ & $1.1 \pm 0.005$ & 1.1 & 0.27 & 0.59 \\
\hline
\end{tabular}




\section{Assessment of the groundwater quality using WQI}

The WQI datasets resulting from the 50 samples ranged from 49 to 136 and were categorized accordingly as being excellent water, good water and poor water (Table 5). Majority of the water samples $3(60 \%)$ were classified as "poor water" whereas $1(20 \%)$ was classified as "good water" and $1(20 \%)$ was classified as "excellent water". None of the water samples had WQI within the categories of "very poor water". Poor water was observed in the sampling locations. S1, S2 and S3 were classified as poor water. This reflects the presence of anthropogenic pollution sources within the basin. The table also shows high values of the quality rating (qi) for most studied characteristics, especially the concentration of lead $(\mathrm{Pb})$ which increased the sub-index values (Sli) and therefore to reflect in the water quality index values (WQI). This deterioration in the quality of the groundwater at the Woreillu town was due mainly to the increase in the amount of lead as well as high concentrations of salts such as total dissolved solid, total Alkalinity and total Hardness as shown (Table 4).

Table 5 the quality rating, sub index and WQI values of the studied under ground water for drinking purposes

\begin{tabular}{|l|l|l|l|l|l|l|l|l|l|l|}
\hline \multirow{2}{*}{ parameters } & S1 & S2 & S3 & S4 & S5 \\
\cline { 2 - 11 } & Qi & SIi & Qi & SIi & Qi & SIi & Qi & SIi & Qi & SIi \\
\hline Temp. & 54.2 & 1.154 & 51.28 & 1.902 & 44 & 0.9372 & 60 & 1.278 & 64 & 1.363 \\
\hline $\mathrm{P}^{\mathrm{H}}$ & 104 & 8.850 & 108 & 9.191 & 105.3 & 8.961 & 105.3 & 8.961 & 110.7 & 9.4206 \\
\hline $\mathrm{EC}$ & 0.03 & 0.0026 & 0.033 & 0.0028 & 0.035 & 0.0030 & 0.03 & 0.0026 & 0.035 & 0.0030 \\
\hline Turbidity & 77.8 & 4.96 & 76 & 4.85 & 82 & 5.23 & 136 & 8.68 & 62 & 3.96 \\
\hline TDS & 19.58 & 1.67 & 21 & 1.79 & 23.4 & 1.99 & 19.3 & 1.64 & 20.7 & 1.76 \\
\hline TH & 35.7 & 2.28 & 52.6 & 3.36 & 43 & 2.74 & 39.4 & 2.51 & 29.6 & 1.89 \\
\hline Alkalinity & 82.5 & 3.51 & 60.5 & 2.58 & 84.5 & 3.60 & 89.5 & 3.81 & 70 & 2.98 \\
\hline Nitrate & 0.36 & 0.038 & 0.38 & 0.040 & 0.46 & 0.049 & 0.38 & 0.040 & 0.34 & 0.036 \\
\hline Phosphate & 13 & 0.277 & 5 & 0.107 & 2 & 0.043 & 11.6 & 0.247 & 5.4 & 0.115 \\
\hline Sulphate & 8.8 & 0.749 & $5 . .76$ & 0.490 & 9.2 & 0.783 & 2.2 & 0.187 & 1.76 & 0.150 \\
\hline Fe & 42 & 2.68 & 30 & 1.91 & 34 & 2.17 & 56 & 3.57 & 106 & 6.76 \\
\hline Cu & 4.5 & 0.192 & 5 & 0.213 & 5 & 0.213 & 6.5 & 0.278 & 5.5 & 0.234 \\
\hline Pb & 1000 & 106.4 & 200 & 21.28 & 200 & 21.28 & 800 & 85.12 & 900 & 95.76 \\
\hline Mn & 27.5 & 2.34 & 12.5 & 1.06 & 10 & 0.851 & 10 & 0.851 & 17.5 & 1.49 \\
\hline Zn & 12.75 & 0.543 & 17.25 & 0.735 & 6.75 & 0.288 & 9.5 & 0.405 & 27.5 & 1.17 \\
\hline$\sum($ SIi $)=$ WQI & 136 & & 50 & & 49 & & 118 & & 127 & \\
\hline Water type & Poor & & Good & Excellent & Poor & & Poor \\
\hline
\end{tabular}

The effective weight values of each water quality parameter are obtained by Equation (5). The summary statistics (maximum, minimum, mean and standard deviations) of the effective weight values of each water quality parameter in all studied locations are present in Table 6 . Among the selected water quality parameters, lead, $\mathrm{pH}$ and turbidity exhibit the largest mean effective weight values compared to the other parameters with effective weight of $62.58 \%, 11.67 \%$ and $6.92 \%$, respectively. Thus, these parameters are considered as the most effective parameters in the WQI values. The relative weight of these three parameters were also confirms this fact Table 2. On the other hand, the parameters $\mathrm{EC}, \mathrm{NO}_{3}{ }^{-}, \mathrm{PO}_{4}{ }^{3-}, \mathrm{SO}_{4}{ }^{2-}, \mathrm{Cu}$ and $\mathrm{Zn}$ showed low mean effective weight values. These observations are primarily due to the measured concentration values of these parameters in water samples in were very small as compared to their maximum allowable limit values, as prescribed by WHO. 
Table 6. Summary statistics of effective weight values for each water quality parameter

\begin{tabular}{|c|c|c|c|c|c|c|c|c|c|}
\hline \multirow[t]{3}{*}{ Parameters } & \multicolumn{9}{|c|}{ Effective weight (\%) } \\
\hline & \multicolumn{5}{|c|}{ Sampling Sites } & \multirow{2}{*}{ Max } & \multirow{2}{*}{ Min } & \multirow{2}{*}{ Mean } & \multirow{2}{*}{ SD } \\
\hline & S1 & S2 & S3 & S4 & S5 & & & & \\
\hline Temperature $\left({ }^{\circ} \mathrm{C}\right)$ & 0.85 & 3.84 & 1.91 & 1.15 & 1.07 & 3.84 & 0.85 & 1.76 & 1.09 \\
\hline $\mathrm{P}^{\mathrm{H}}$ & 6.52 & 18.56 & 18.24 & 7.62 & 7.41 & 18.58 & 6.52 & 11.67 & 5.50 \\
\hline $\mathrm{EC}(\mu \mathrm{S} / \mathrm{Cm})$ & 0.002 & 0.006 & 0.006 & 0.002 & 0.002 & 0.006 & 0.002 & 0.004 & 0.002 \\
\hline Turbidity (NTU) & 3.66 & 9.80 & 10.64 & 7.38 & 3.12 & 10.64 & 3.12 & 6.92 & 3.07 \\
\hline TDS (mg/L) & 1.23 & 3.62 & 4.02 & 1.39 & 1.38 & 4.02 & 1.23 & 2.33 & 1.22 \\
\hline $\mathrm{TH}(\mathrm{mg} / \mathrm{L})$ & 1.68 & 6.79 & 5.58 & 2.13 & 1.49 & 6.79 & 1.49 & 3.53 & 2.21 \\
\hline Alkalinity $(\mathrm{mg} / \mathrm{l})$ & 2.59 & 5.21 & 7.33 & 3.24 & 2.34 & 7.33 & 2.34 & 4.14 & 1.89 \\
\hline Nitrate $(\mathrm{mg} / \mathrm{L})$ & 0.028 & 0.081 & 0.10 & 0.034 & 0.028 & 0.1 & 0.028 & 0.054 & 0.030 \\
\hline Phosphate $(\mathrm{mg} / \mathrm{L})$ & 0.20 & 0.22 & 0.09 & 0.21 & 0.09 & 0.22 & 0.09 & 0.162 & 0.059 \\
\hline Sulphate $(\mathrm{mg} / \mathrm{L})$ & 0.55 & 0.99 & 1.59 & 0.16 & 0.12 & 1.59 & 0.12 & 0.682 & 0.552 \\
\hline $\mathrm{Fe}(\mathrm{mg} / \mathrm{L})$ & 1.98 & 3.86 & 4.42 & 3.04 & 5.32 & 5.32 & 1.98 & 3.72 & 1.14 \\
\hline $\mathrm{Cu}(\mathrm{mg} / \mathrm{L})$ & 0.14 & 0.43 & 0.43 & 0.24 & 0.18 & 0.43 & 0.14 & 0.284 & 0.123 \\
\hline $\mathrm{Pb}(\mathrm{mg} / \mathrm{L})$ & 78.44 & 42.98 & 42.98 & 72.39 & 76.13 & 78.44 & 42.98 & 62.58 & 16.12 \\
\hline $\mathrm{Mn}(\mathrm{mg} / \mathrm{L})$ & 1.73 & 2.14 & 1.73 & 0.72 & 1.17 & 2.14 & 0.72 & 1.49 & 0.496 \\
\hline $\mathrm{Zn}(\mathrm{mg} / \mathrm{L})$ & 0.40 & 1.48 & 0.59 & 0.35 & 0.92 & 1.48 & 0.35 & 0.748 & 0.418 \\
\hline
\end{tabular}

\section{Conclusions}

Based on the findings, it is evident that not all the borehole water samples investigated had parameters that were in conformity with the WHO (2011) recommended permissible limits for drinking water. Therefore, possible adverse effect due to consumption of the water containing high levels of these parameters may occur among the inhabitants of this study area especially in the cases of lead, it bio-accumulates beyond the tolerable concentrations in the body, and turbidity, it can provide shelter for opportunistic microorganisms and pathogens in water. The study also showed that the ground water in the study area water was hard water in all sampling sites. This may not be a problem for drinking since it would help to improve calcium and magnesium content in the body. It would only pose problems when the water is used for washing since more soap would be consumed.

The WQI was applied to estimate the groundwater quality and its portability to drinking usage. Owing to results of the WQI, $20 \%$ of groundwater samples denote "excellent water", $20 \%$ show "good water" and $60 \%$ of the ground water show "poor water" class. This result reveals that the samples in most wells decrease its suitability for drinking. The study also indicated that lead, $\mathrm{pH}$ and turbidity were the most effective parameters in the WQI values. The main pollution sources responsible for variation in groundwater quality come from industrial effluents, domestic and agricultural runoff through anthropogenic processes and natural influence. The study, therefore, recommends the need for regular monitoring of groundwater levels and adopting appropriate measures to overcome pollution and facilitate sustainable groundwater quality of the basin.

\section{References}

Al-Hamdany, A. S. and Al-Saffawi, A. Y. T. (2018a). Evaluation of the groundwater quality of the right side of Mosul city for drinking purposes using the water quality index (WQI). Accepted for publ. in the Proceed of the First Int. Conf. and the third scientific of the Faculty of Science, Univ. of Tikrit, 17-18 December 2018. Iraq.

APHA (2005). Standard Methods for the Examination of Water and Wastewater (21 $1^{\text {st }}$ editi). Washington, DC: American Public Health Association.

ASTM (2004). American society for testing materials Annual book of Standard Water and environmental technology. Vol. 11 Pp 22-132.

Balakrishnan, P., Saleem, A. and Mallikarjun, N.D., (2011). Groundwater quality mapping using geographic information system (GIS): A case study of Gulbarga City, Karnataka, India Afr J Environ Sci Tech. 5 (12), $1069-1084$

Barakat, M. A. (2011). New trends in removing heavy metals from industrial waste water. Arabian Journal of Chemistry, 4(4), 361-377.

Bowell, R. J., McEldowney, S., Waren, A., Mattew, B. and Bawankuzo, M. (1996). Biogeochemical factors affecting borehole water quality in central Tanzania, Environmental geochemistry and health: geological society, London.

Brown, R. M., McClelland, N. I., Deininger, R. A., \& Tozer, R. G. (1970). A Water Quality Index: Do We Dare? Water Sewage Works, 117(10), 339-343.

Chowdhury, S., Mazumder, M. A. J., Al-Attas, O. \& Husain, T. (2016). Heavy metals in drinking water: 
Occurrences, implications, and future needs in developing countries. Science of the total environment, 569$570,476-488$.

Devojee, B., Nagababu, M., Kumar, M., Nandioni,Y. and Hemakumar,H.V. (2018). Assessment and mapping of irrigation water quality index of Baptla Mandal, Guntur distric, Andhr, India. Int. J. Curr. Microbial. App. Sci., 7(1), 1914-1920.

Environmental Protection Agency, Ghana (2002). National action programme to combat drought and desertification.

Gardner, S.J. and Pelig-Ba, K.B. (1995). Health problems related to ground waters in the Obuasi and Bolgatanga areas, Ghana. British Geological Survey Technical Report, WC/95/43

Kumar, G., Chinmaya, M., Divya, S., Abhay, K., Jayant, K. \& Sudhir, K. (2015). Evaluation of ground water quality in the Chotanagpur plateau region of the Subarnaretha river basin, Jharhand state, India.ScienceDirect, 6(1), 57-74.

Mancy J.W. (2012). The Environmental Impact of Agricultural Nitrogen and Phosphorus Use. Journal Agric Food Chem., 30: 804-810.

Nitsch, C., Heitland, H-J., Marsen, H. And Schlüssler, H-J. (2000). Cleansing agents. In: Ullmann's encyclopedia of industrial chemistry (on-line). Wiley-VCH Verlag GmbH \& Co. KGaA, Weinheim, pp. 1-23

Nkansah, M. A. and Ephraim, J. H. (2009). Physiocochemical studies of water from selected boreholes in Bosomtwi-Atwima-Kwanwoma district of Ghana. Pacific Journal of Science and Technology 10(2):643-648.

Onwughara, N.I., Ajiwe, V.I., \& Nnabuenyi, H.O. (2013).Physico-chemical studies of water from selected boreholes in Umuhia North, Nigeria. International Journal of Pure \& Applied Bioscience, 1(3), 34-44.

Quaitto, W.A. (1996). Ultimate Chemistry. Pixelimage Accra, pp. 105-110.

Ramadhan, O. M., Al-Saffawi, A. Y. T., Al-Mashhdany, M. H. S. (2018). Assessment of Surface Water Quality for Irrigation using WQI model; A Case Study of Khosar and Tigris Rivers. Int. J. of Enhanced Res. in Sci., Techn. and Engin, 7( 3),63-69.

Remesan, R. and Panda, R.K., (2008). The $3^{\text {rd }}$ International Conference on Water Resources and Arid Environments.

Sahu, P., \& Sikdar, P. K. (2008). Hydrochemical framework of the aquifer in and around East Kolkata Wetlands, West Bengal, India. Environmental Geology, 55(4), 823-835.

Sawyer, C.N., McCarty, P.L., \& Parkin, G.F. (2003). Chemistry for Environmental Engineering and Science (5th Ed.). Boston: McGraw-Hill Education.

Sener, S., Sener, E., \& Ayşen, D. (2017). Evaluation of water quality usingwater quality index. (WQI) method and GIS in Aksu River (SW-Turkey). Science of the Total Environment, 585, 131-144

Spellman, F.R. and Drinan, J.E. (2012). The drinking water handbook, 2nd edn. CRC Press, Boca Raton.

Sujatha, D., \& Reddy, B. R. (2003). Quality characterization of groundwater in the south-eastern part of the Ranga Reddy district, Andhra Pradesh, India. Environmental Geology, 1(44), 579-586.

Thriodore, B. S. (2004). Interpreting Drinking Water Quality. New Brunswick. Cook College, Rutgers University. Tiimub, B. M., Kuffour, R. A., Aeratia, G. A. (2012). Quality determination of ground water for drinking at Nkawkaw in Eastern region of Ghana. Civil and environmental research, 2 (9), 2852-2860.

Todd, D.K. (2008) .Groundwater hydrology, 3rd edn. Wiley, Hoboken

United States Environmental Protection Agency (2012). Total Alkalinity. In Water Monitoring and Assessment. USEPA (2012). Drinking water standards and health advisories.

Ward, N. I. (1995). Environmental Analytical Chemistry, Blackie Academic and professional. Chapman and Hall; London U.K., pp.121-127.

WHO (1996). Guidelines for drinking water quality, Volume 2, Health Criteria and Other Supporting Information (2nd Ed., Vol. 1). Geneva, Switzerland: World Health Organization.

WHO (2004). Guidelines for drinking water quality. Recommendation (2nd ed. Vol.1) AUBS publishers New Delhi pp. 122-143.

WHO (2011). Guidelines for Drinking-Water Quality, 4th Edition. Geneva: World Health Organization.

WHO (2011a). Guidelines for drinking-water quality (fourth edi). Geneva: World Health Organization.

WHO (2011b). Hardness in drinking-water. Background document for preparation of WHO Guidelines for drinking-water quality. Geneva: World Health Organization. 